\title{
El-Fayah
}

JURNAL BIOLOGI

Journal Homepage: http://ejournal.uin-malang.ac.id/index.php/bio/index

e-ISSN: 2460-7207, p-ISSN: 2086-0064

\section{Characteristics of Goat Ovarium Granulosa Cells With Extract Leaves (Schleichera oleosa) at Different Passage Levels in Vitro}

\section{Lil Hanifah' and Roihatul Muti’ah²}

${ }^{1}$ Biology Studi Program, Science and Technology Faculty, UIN Maulana Malik Ibrahim Malang, Jl. Gajayana no. 50 Malang

${ }^{2}$ Pharmacy Study Program, Medical and Health Science Faculty, UIN Maulana Malik Ibrahim Malang, Jl. Gajayana no. 50 Malang

*Corresponding author

Email: : lil.hanifah5@gmail.com

DOI: 10.18860/elha.v8i1.11419

\section{Article Info}

Article history:

Received 12 December 2019

Received in revised form

03 April 2020

Accepted 15 june 2020

Key Word:

Granulose Cells,

Kesambi Leaf Extract,

Passage,

In Vitro

\begin{abstract}
S. oleosa belongs to the Sapindaceae family and has phytochemicals phenolic acid so that it has enormous benefits in the process antioxidant. The presence of antioxidant activity in cells can affect the defense of the cell protein membrane, so that the ability of cells to perform division is optimal. In vitro this is mostly done by adding hormones to cell culture media or natural compounds to increase cell proliferation. Every population of cell that has undergone division during the proliferation process to confluent is an indication that the cell is aging. This study was an experimental study was designed using a completely randomized design (CRD) with 5 treatments and 5 replications as follows: Ko: granulose cells and culture media without treatment ( $0 \mu l)$, P1: granulose cells and culture media with $1 \%$ kesambi leaf extract. $(30 \mu \mathrm{l}), \mathrm{P}_{2}$ : granulose cells and culture media given kesambi leaf extract 1.5\% $(45 \mu \mathrm{l}), \mathrm{P}_{3}$ : granulose cells and culture media given kesambi leaf extract $2 \%(60 \mu l)$ and P4: granulosa cells and the culture media was given $2.5 \%(75 \mu l)$ to the leaves extract., the characteristics of goat ovarian granulosa cells by giving kesambi (Scheichera oleosa) leaf extract at different passages were at the level of confluence showing the highest value in passage I, namely treatment P1. Meanwhile, the level of viability shows the highest value in section I, namely the $P_{4}$ treatment.
\end{abstract}

\section{INTRODUCTION}

S. oleosa is a tropical forest tree plant of the Sapindaceae family, which is spread in South and Southeast Asia (Cambodia, India, Indonesia, Myanmar, Sri Lanka, Thailand and
Vietnam (CABI, 2020) (Anuragi \& Mishra, 2017). Kesambi plant is also known by the name of the area: kasambi (Sunda); kesambi, kusambi, sambi (Java and Bali); kasambhi (Madura); kusambi, usapi (East Timor); kasembi, kahembi 
(Sumba); Kehabe (Sawu); kabahi (Solor); kalabai (Alor); kule, ule (Rote); bado (Makassar); ading (Bugis) (Panche et al., 2016).

S. oleosa has low tannin content, making it good for animal feed. However, it has very important phytochemical elements, including terpenoids, falvonoid, phenolic acid, betulin, betulin acid and others, so that it has enormous benefits in the process of antimicrobial, antioxidant, anti-cancer and can be used for biodiesel production (Anuragi and Mishra, 2017).

Several studies have shown that plants containing phenols also have antioxidant properties. Polyphenols derived from natural materials have simple structures such as phenolic acids, phenylpropanoids, and others. One of the potential abilities of kesambi as an antioxidant is due to its phenolic compounds. Fenolic acid as a terapheutic antioxidant agent contributes to reducing free radicals, reducing exposure to harmful metals, and influencing cell signaling pathways and gene expression (Bhatia et al., 2013).

One of the characteristics of cells that have good growth is that they can maintain their protein membrane. The presence of antioxidant activity in cells can affect the defense of the cell protein membrane (Waseh, 2016). The granulosa cells in the ovaries have an important role for reproduction. Because granulosa cells have a function as a provider of nutrition for oocyte growth. If the available nutrients from granulosa cells are in sufficient numbers, then the oocyte or ovum will grow well. So that the process of maturation or maturation of the ovum will be good too (Waseh, 2016).

In vitro this is mostly done by adding hormones to cell culture media or natural compounds to increase cell proliferation. Several studies have shown that the presence of antioxidant activity in dragon scales has an effect on the maturity level of goat ovary follicles (Hati, 2016).

The addition of Growth Factor Hormone (GFH) can also increase cell proliferation. The use of GFH derived from stem cells still contains controversy in several countries, so it is necessary to have an alternative Growth Factor derived from plants that has the potential to be a Growth Factor. The process of adding Growth Factor will affect cell proliferation in the in vitro culture process (Arundina \& Suardita, 2014).

In the in vitro culture process, cells originating from tissues or organs that have been mechanically or enzymatically broken down become cell suspensions which are cultured and develop into a single layer of tissue (monolayer) on a hard surface such as a flask and can be renewed through subculture. (passages) in order to obtain sustainable cells (cell line)(Sumiati et al., 2009). The cell culture passage process is important for the cell culture laboratory. Every cell population that has undergone division during the proliferation process to confluent is an indication that the cell is aging (Kwist et al., 2016). Therefore, this study aims to determine the characteristics of goat ovarian granulosa cells by giving kesambi leaf extract at different levels of passage. So the hope is that by giving the extract, cells that have resistance will be produced, so that sustainable cells are formed.

\section{MATERIALS AND METHODS}

\section{Tools and Materials}

The tools used in this research include: Laminar Air Flow (LAF) (Labtech) analytical scales (Sartorius), $\mathrm{CO}_{2}$ incubator 5\% (Thermo Scientific), oven (Thermo Scientific), autoclav (Labtech), inverted microscope (Nikon), Countess Cell (Invitrogen Thermo Fisher Scientific), Tissue Culture Dish $30 \mathrm{~mm}$ (Iwaki), centrifuge (Biofuge Thermo Scientific), bottle screw cap, erlenmeyer, $50 \mathrm{~mL}$ beaker glass, petri dish, surgical scissors, tweezers, $10 \mathrm{cc}$ syringe, aluminum foil, $15 \mathrm{~mL}$ centrifuge tube, $0.20 \mu \mathrm{m}$ filter membrane, bunsen, blue tip, yellow tip, 20-200 $\mu$ micropipette , 100-1000 $\mu$, hand gloves, masks, label paper and tissue.

The materials used in this study included: goat ovary obtained from the Malang Breadfruit Slaughterhouse, TCM 199 media, 
aquades, Physiological $\mathrm{NaCl}$ (0.9\%), 70\% alcohol, penicillin, streptomycin, $\mathrm{NaHCO}_{3}$, hepes. , deionized water (DI), Fetal Bovine Serum (FBS) and typol

\section{Kesambi Leaf Extraction}

The extraction stage was carried out using the maceration method, namely by soaking $100 \mathrm{~g}$ of simplicia kesambi (Schleichera oleosa) with $96 \%$ methanol $100 \mathrm{ml}$ (1: 5) for $2 \times 24$ hours. After $2 \times 24$ hours the immersion is filtered using filter paper, then evaporation is carried out using a Rotary Evaporator. If the resulting extract is in the form of a paste, the extract is ready for use.

\section{Making Media Stock TCM 199}

Weighed 1.35 grams of TCM, 0.37, 0.37 grams of $\mathrm{NaHCO}_{3}, 0.006$ grams of penicillin, 0.01 grams of streptomycin and 0.23 grams of liver. All of these materials were dissolved with $100 \mathrm{ml}$ of sterile deionized water (DI), then homogenized using a magnetic stirrer and filtered with $0.22 \mu \mathrm{m}$ millipore membrane. Then put it in a screw cap bottle and stored at $40 \mathrm{C}$. The media stock is ready for use.

\section{Granulose Cell Culture}

In the laboratory, the collected ovaries were transferred into a collection bottle containing $100 \mathrm{ml} \mathrm{NaCl}, 0.006 \mathrm{gr}$ pinicillin and $0.01 \mathrm{~g}$ streptomycin which had been prepared in a waterbath at a temperature of $370 \mathrm{C}$. Under sterile conditions, follicular fluid was aspirated to obtain granulosa cells using a 10 $\mathrm{ml}$ disposable syringe and a $21 \mathrm{G}$. needle. Placed the aspiration results in a centrifuge tube. Added $2 \mathrm{ml} \mathrm{TCM} 199$ 0\%. Centrifuged at $1000 \mathrm{rpm}$ for 5 minutes. The supernatant was removed and $2 \mathrm{ml} \mathrm{TCM} 199$ 5\% was added. Centrifuged at $1000 \mathrm{rpm}$ for 5 minutes. The supernatant was removed and $2 \mathrm{ml}$ TCM 199 $10 \%$ was added again. Centrifuged at $1000 \mathrm{rpm}$ for 5 minutes. The supernatant was removed and $100 \mu \mathrm{m}$ of granulosa cell pellets were taken.

\section{Passage of Granulosa Cell Culture}

Cell proliferation observations were carried out to determine the growth of granulosa cells before and after dficulture. Granulosa cell proliferation was observed based on the level of cell attachment to the substrate and cell expansion using an inverted microscope. After the cells grow and develop to reach a confluence above 50\%, passages are immediately carried out to obtain a more stable tissue growth as a monolayer.

Granulosa cells that have filled the bottom of the plate (confluent) are pasaged using the trypsination process. The explants were taken from the dish, then the culture medium was discarded and the cells were rinsed using PBS, then $500 \mu \mathrm{l}$ of $0.25 \%$ trypsin was added and left for a few minutes. Cells undergoing the trypsination process will be separated from each other which is marked by their rounded shape. The process of releasing cells from the bottom of the plate is done by shaking the plate. Tripsination is terminated after the cells are released from the bottom of the plate by adding culture medium. The granulosa cell suspension was collected using a $15 \mathrm{ml}$ centrifugation tube. Cell samples from the suspension were counted using Automatic Counter Cell. $10 \mu \mathrm{l}$ of cell samples were taken, then mixed with $10 \mu \mathrm{l}$ of trypan blue and dropped into the chamber as much as $10 \mu \mathrm{l}$. The number of cells will be counted on the tool, so that the level of viability of the cells can be determined. Cell passages were carried out 3 times

\section{RESULTS}

\section{Confluence Level of Goat Ovarian Granulosa Cells by Giving Kesambi Leaf Extract (Scheichera oleosa) at Different Passage Levels}

The level of confluence of goat ovarian granulosa cells in this study can be seen through the attachment to the substrate and cell expansion. Based on the observations, giving kesambi leaf extract with different 
doses responded to different confluences in goat ovarian granulosa cells in each passage. Observations were made on the 7th day after planting with different treatments, namely: $\mathrm{K}$ (0\%): TCM-199 $2700 \mu \mathrm{l}$ media + FBS $300 \mu \mathrm{l}, \mathrm{P} 1$ (1\%): TCM-199 $2670 \mu \mathrm{l}$ media + FBS $300 \mu \mathrm{l}+$ kesambi leaf extract $30 \mu \mathrm{l}, \mathrm{P} 2$ (1.5\%): TCM media $-1992655 \mu \mathrm{l}+$ FBS $300 \mu \mathrm{l}+45 \mu \mathrm{l}$ of kesambi leaf extract, P3 (2\%): TCM-199 $2640 \mu \mathrm{l}$

Based on Figure 4.1 it can be seen that There are differences in the level of confluence in each treatment of kesambi leaf extract (Scheichera oleosa) at different levels of passage, namely passage I, passage II and passage III. the difference is indicate with the protrusion - protruding cells that are formed. The expansion (expansion) of the cell indicates that the cell has undergone a lot of proliferation, thus forming expansion and experiencing a high degree of confluence.
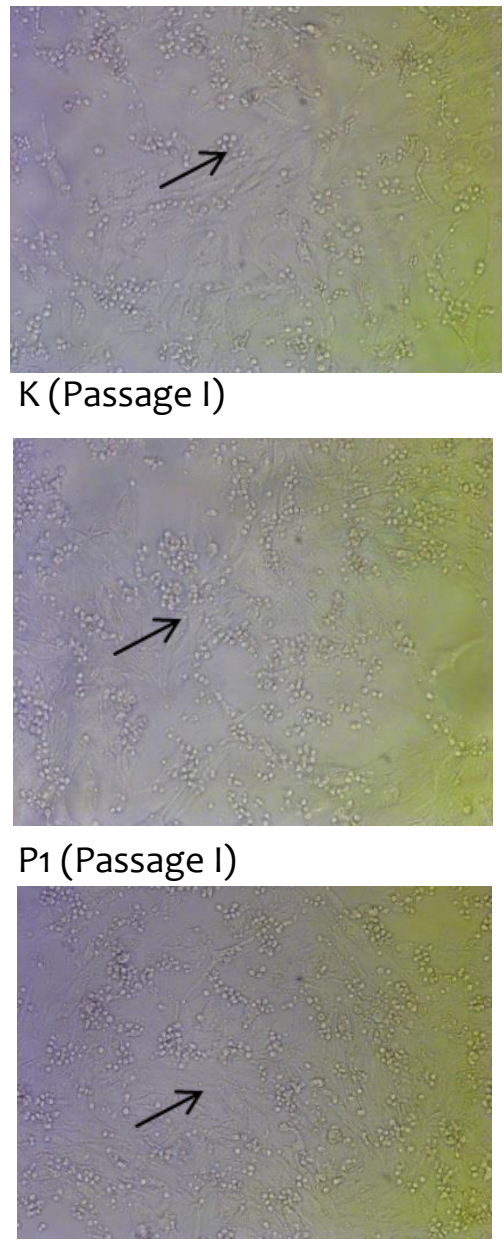

P2 (Passage I)
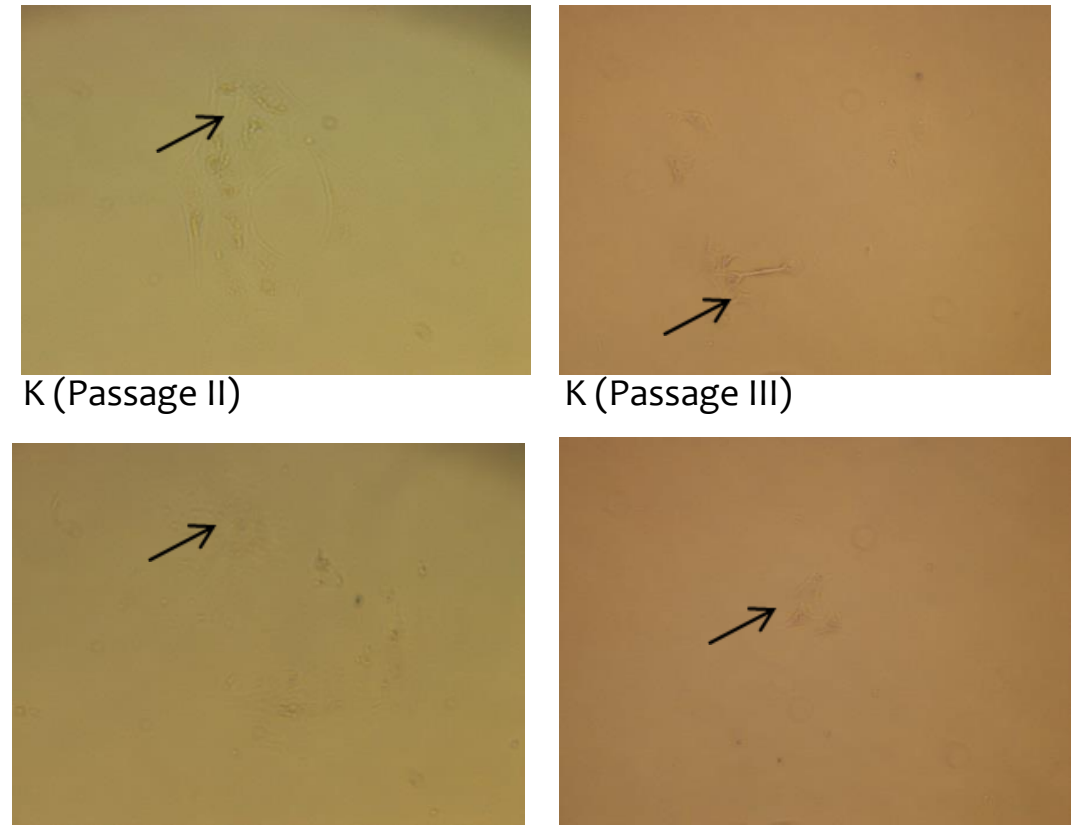

P1 (Passage II)

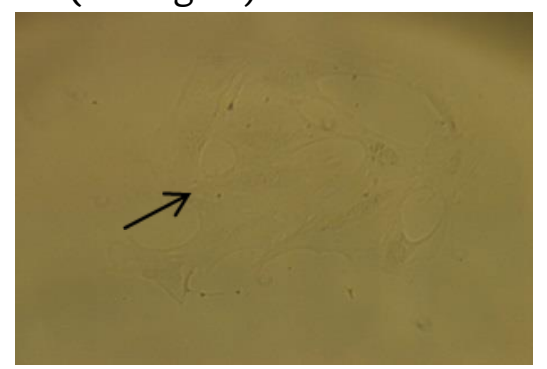

P2 (Passage II)

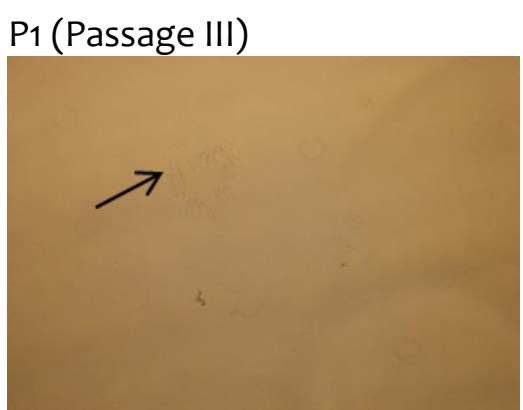

P2 (Passage III) 

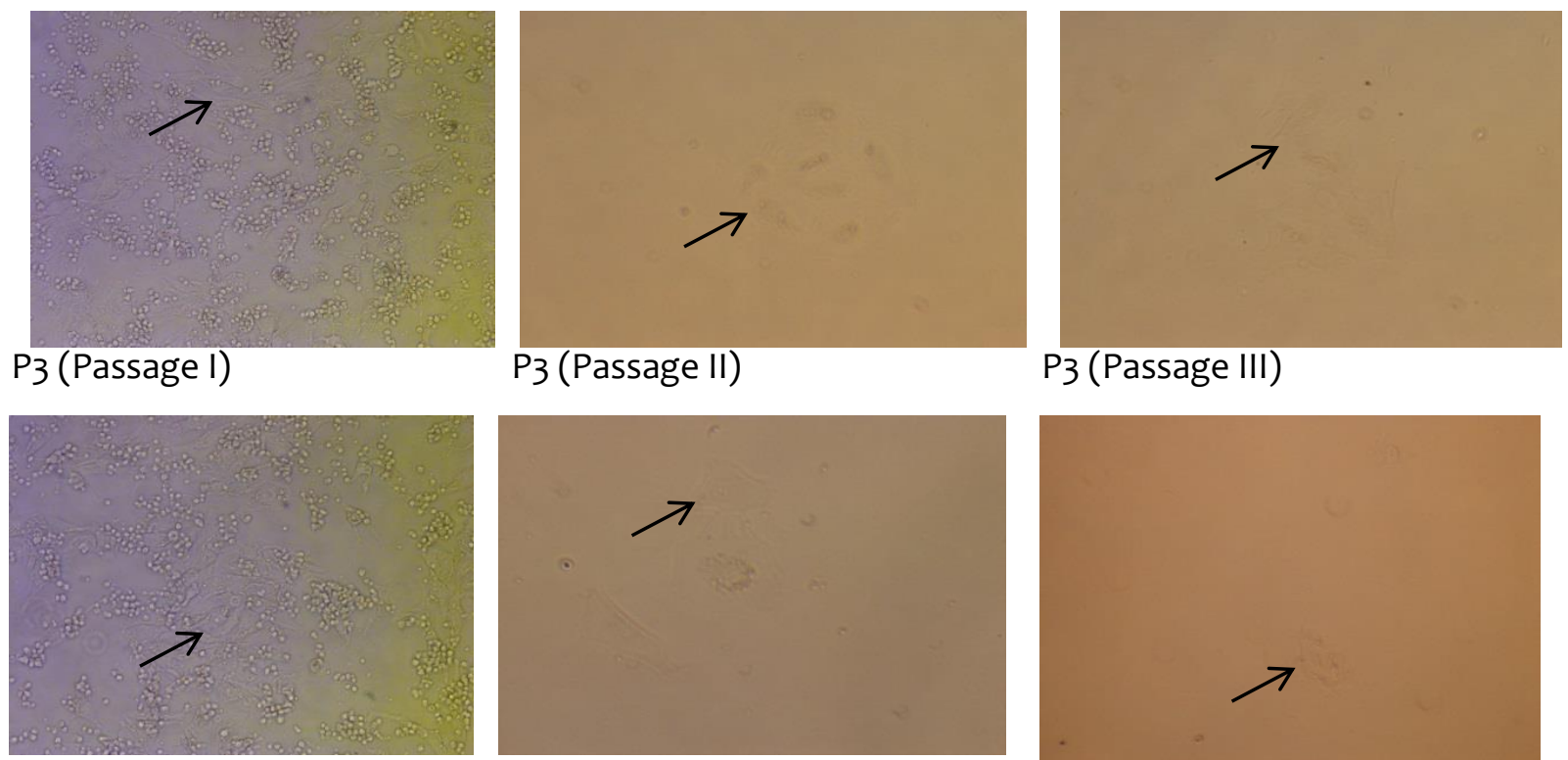

P3 (Passage III)

P4 (Passage I)

P4 (Passage II)

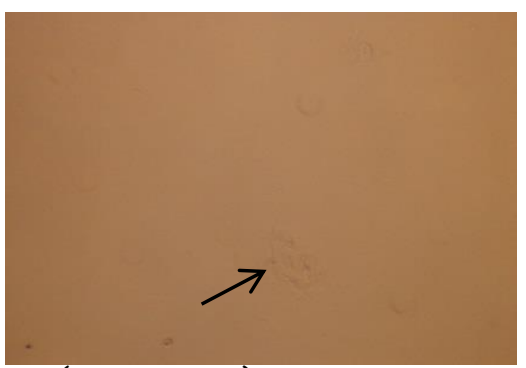

P4 (Passage III)

Figure 4.1 Confluence level of goat ovarian granulosa cells by administering kesambi leaf extract (Scheichera oleosa) in different passages. (K) Granulosa cell culture without giving kesambi leaf extract (control) at the levels of passages I, II and III, (P1) Granulosa cell culture with $1 \%$ of kesambi leaf extract at the levels of passages I, II and III, ( $\mathrm{P}_{2}$ ) Cell culture granulosa by giving kesambi leaf extract $1.5 \%$ at the levels of passages I, II and III, ( $\mathrm{P}_{3}$ ) Granulose cell culture by giving $2 \%$ kesambi leaf extract at the levels of passages I, II and III and (P4) Culture of granulosa cells by giving the extract kesambi leaves $2.5 \%$ at passages I, II and III. The arrows indicate cells that have undergone expansion. The image was observed using a Nikon Ti-U Inverted Microscope with a magnification of 10 × 20

Confluence level of goat ovary granulosa cells by giving kesambi leaf extract (Scheichera oleosa) can be seen in the following table

Table 1. Level of confluence of goat ovarian granulosa cells by giving kesambi leaf extract (Scheichera oleosa) at different levels of passage

\begin{tabular}{llll}
\hline Dose Treatment & Passage \pm SD & & \\
\cline { 2 - 4 } & I & II & III \\
\hline $\mathrm{K}(0 \%) 0 \mu \mathrm{l}$ & $19.01 \pm 1.24 \mathrm{a}$ & $0.49 \pm 0.24 \mathrm{a}$ & $2.16 \pm 0.61 \mathrm{a}$ \\
\hline $\mathrm{P} 1(1 \%) 30 \mu \mathrm{l}$ & $19.87 \pm 1.56 \mathrm{a}$ & $2.83 \pm 2.09 \mathrm{~b}$ & $1.14 \pm 0.54 \mathrm{a}$ \\
\hline $\mathrm{P} 2(1.5 \%) 45 \mu \mathrm{l}$ & $19.60 \pm 2.28 \mathrm{a}$ & $2.64 \pm 2.8 \mathrm{ob}$ & $0.75 \pm 0.17 \mathrm{~b}$ \\
\hline $\mathrm{P}_{3}(2 \%) 60 \mu \mathrm{l}$ & $18.97 \pm 1.60 \mathrm{~b}$ & $2.44 \pm 2.76 \mathrm{~b}$ & $0.73 \pm 0.33 \mathrm{~b}$ \\
\hline $\mathrm{P}_{4}(2.5 \%) 75 \mu \mathrm{l}$ & $18.83 \pm 2.64 \mathrm{~b}$ & $0.80 \pm 0.38 \mathrm{a}$ & $0.73 \pm 0.06 \mathrm{~b}$ \\
\hline
\end{tabular}

Different notation letters in the same column indicate significantly different $(\mathrm{p}<0.05)$

\section{Level of Viability of Goat Ovarian Granulosa Cells by Giving Kesambi (Scheichera oleosa) Leaf Extract at Different Pasase Levels}

Observation of the level of viability of goat ovarian granulosa cells by administering kesambi leaf extract (Scheichera oleosa) at different levels of passage in this study aims to determine the level of viability of cells after giving kesambi leaf extract on culture media. This can be seen in the table below. 
Table 2. The level of viability of goat ovary granulosa cells by administering kesambi leaf extract (Scheichera oleosa) at different levels of passage

\begin{tabular}{llll}
\hline Dose Treatment & \multicolumn{3}{c}{ Passage \pm SD } \\
\hline $\mathrm{K}(0 \%) 0 \mu \mathrm{l}$ & $17.44 \pm 5.55 \mathrm{a}$ & II & III \\
\hline $\mathrm{P} 1(1 \%) 30 \mu \mathrm{l}$ & $22.14 \pm 16.86 \mathrm{~b}$ & $20.57 \pm 5.88 \mathrm{a}$ & $19.14 \pm 40 \pm 5.63 \mathrm{a}$ \\
\hline $\mathrm{P} 2(1.5 \%) 45 \mu \mathrm{l}$ & $20.19 \pm 4.98 \mathrm{~b}$ & $20.71 \pm 16.32 \mathrm{a}$ & $16.98 \pm 7.46 \mathrm{~b}$ \\
\hline $\mathrm{P} 3(2 \%) 60 \mu \mathrm{l}$ & $21.47 \pm 15.57 \mathrm{~b}$ & $15.46 \pm 4.86 \mathrm{~b}$ & $13.69 \pm 4.33 \mathrm{a}$ \\
\hline $\mathrm{P} 4(2.5 \%) 75 \mu \mathrm{l}$ & $22.79 \pm 10.19 \mathrm{~b}$ & $13.69 \pm 4.33 \mathrm{~b}$ & $15.33 \pm 5.38 \mathrm{~b}$ \\
\hline Different notation letters in the same column indicate significantly different $(\mathrm{p}<0.05)$ &
\end{tabular}

\section{DISCUSSION}

Based on the results of the calculation of the level of confluence Goat ovarian granulosa cells with the administration of kesambi leaf extract (Scheichera oleosa) at different levels of passage showed that in passage I the value of the level of confluence in treatment $\mathrm{K}, \mathrm{P} 1$ and $\mathrm{P}_{2}$ did not show any significant differences, as well as the confluence value of treatment $\mathrm{P}_{3}$ and $\mathrm{P}_{4}(\mathrm{p}<0.05)$. However, there are significant differences in $\mathrm{P}_{2}$ and $\mathrm{P}_{3}$ treatment ( $p<0.05)$. The value of the level of confluence of each treatment in passage I has decreased. The highest confluence value is in the $\mathrm{P} 1$ treatment.

In the second passage, the confluence level of ovarian granulosa cells in $\mathrm{K}$ and $\mathrm{P} 4$ treatment did not show any significant differences $(p<0.05)$. However, there are significant differences in the treatment of $\mathrm{P}_{1}$, $P_{2}$ and $P_{3}(p<0.05)$. The value of the highest level of confluence in treatment $\mathrm{P} 1$.

In the third passage, the confluence level of ovarian granulosa cells in $K$ and $P_{1}$ treatment did not show any significant differences $(p<0.05)$. However, there were significant differences in the $\mathrm{P}_{2}, \mathrm{P}_{3}$ and $\mathrm{P}_{4}$ treatments $(p<0.05)$. The highest level of confluence in treatment $\mathrm{K}$.

The value of the level of confluence of each treatment at different passage levels tended to show a decrease. This is one time triggered by a decreased ability of cells in the proliferation process. The proliferation process requires optimal environmental conditions so that cells can grow and develop properly because they can adapt well so that it can affect the level of confluence.

Cell - cell that has undergone passage basically takes less time to mitosis. Cells that have undergone passase will proliferate faster. This is because these cells have adapted to the culture environment and are increasingly homogeneous (Freshney, 2016).

Pasase is carried out so that the solid cells are immediately cultured again at a low density. This solid condition, if left unchecked, will cause cells to not be able to divide, age or differentiate and then die so that the cell proliferation process does not take place (Budiono, 2018).

Basically, cell proliferation produces two cells derived from one cell. This situation requires cell growth which is then followed by cell division (division). In normal tissue, cell proliferation leads to additional tissue, where the number of cells depends not only on cell proliferation but also by cell death. Programmed cell death (apoptosis) is the process of releasing damaged cells. It is this balance between new cell production and cell death that maintains the proper cells in the tissue (homeostasis) (Sitorus, 2013).

Proliferative activity can be influenced by extracellular and intracellular factors. External factors that affect cell proliferation include growth factors (GF), cyclin and cyclin dependent kinases (cdks), Rb family. Growth factor molecules will be able to function if they are recognized by receptors on the surface of the cell, which are called growth factor receptors (GFR) (Rahmawati, 2014) 
When Growth Factor Receptor (GFR) can be recognized by the receptor, it will cause cells to grow and can attach to the substrate. According to Waseh (2016) in Trenggono (2009), cells that grow and attach to the substrate are the result of selection from cells that can survive after disaggression. Those that do not survive or die will float on the media. Furthermore, the dead cells will be wasted at the time of media change. In this study, media changes were carried out on the $4^{\text {th }}$ day after culture.

According to (Rahmawati, 2014) that the process of cell proliferation is related to the cell cycle in experiencing division. The cell cycle can be differentiated morphologically and biochemically. When viewed biochemically, the cell cycle describes the time period between two consecutive periods of cell division which consists of four regulatory phases, namely gap 1 (G1) for cell growth, DNA synthesis (SI for duplication of raw materials in genetic processes, gap 2 ( $\mathrm{C}_{2}$ ) for repair during cell division where the $G_{1}, S$ and $G_{2}$ phases are simultaneously called interphase while the mitotic phase $(M)$ is for the implementation of cell division, namely nuclear and cytoplasmic division (Sukardja, 2000; Weber, 2007). While in the gap phase o (Go) is called the resting phase in which cells are immobile and do not experience growth.

During the interphase period, the cell produces nutrients and there is duplication of chromatids where these chromatids are directly related to the centromere and have long and short arms. Gap phase 1 (Gt) is the first stage of the interphase phase that takes place between the mitotic phase and before the synthesis phase. In this phase, the cell is prepared for DNA synthesis, the biosynthesis of RNA and protein occurs and produces the enzymes needed in the $S$ phase, especially those needed for DNA replication. The length of the $\mathrm{G} 1$ phase varies greatly even for the same species (Rahmawati, 2014).

The next phase is the $S$ phase. During the $S$ phase, the speed of the RNA transcription process and the protein synthesis process is very low, but the synthesis of histones is very large in this phase. In addition, DNA replication occurs in the $S$ phase, so that at the end of this phase the contents of the DNA are twins and the chromosomes are ready to separate. Phase gap 2 (G2) occurs after the $S$ phase and before the $M$ phase. In the $G_{2}$ phase the cells are ready to divide, the DNA replication process and various proteins and biosynthesis are enhanced. The next stage, the nucleus and cytoplasm separate as 2 child cells in the $M$ phase. The next phase is the mitosis $(M)$ phase where growth and protein synthesis stop during the $M$ phase and the genome cell divides into two identical chromosomes. The length of time in the $M$ phase is shorter than that of the interphase phase, possibly 7-2 hours (Rahmawati, 2014).

The results of this study indicate that the administration of kesambi leaf extract at different levels of passage does not provide a significant difference in the level of confluence, but there are significant differences in several treatments. This can be influenced by the antioxidant activity of kesambi leaf extract (Scheichera oleosa).

The groups of compounds thought to be responsible for the antioxidant activity of kesambi leaf extract based on the color reaction test are phenols, flavonoids and tannins (Holil \& Griana, 2020).

According to Rahmawati, 2014 these flavonoid compounds, polyphenols and tannins are phenolic compounds, namely compounds with an -OH group attached to an aromatic ring carbon. Flavonoids function as effective antioxidants by providing hydrogen atoms to free radicals to form their own free radical products in these compounds. The free radical products of these compounds are resonance stabilized due to the presence of conjugated double bonds and are therefore less reactive than most other free radicals.

The mechanism of antioxidants in neutralizing free radicals is done by giving one electron so that it becomes a more stable 
compound or a termination reaction occurs and radical reactions end or oxidative stress does not occur in cells(Parwata, 2016). When there are no free radicals in cells, the cells will be stable and can divide and grow properly.

Some phytosterols can also act as antioxidants in cells. Phytosterols (plant sterols) are triterpenes which are important structural components of plant membranes, and free phytosterols function to stabilize the phospholipid bilayer in plant cell membranes as well as cholesterol in cell animal membranes (Moreau et al., 2002). Free radicals in cells can produce lipid peroxides which ultimately can cause cell death and the release of MDA and HNE (Rahmawati, 2014). So that these phytosterols can become antioxidants on free exposure to cells, including reproductive cells.

Some of the active ingredients contained in phytosterols can inhibit oxidation, release hydrogen from antioxidants, release electrons from antioxidants, add fat in aromatic rings to antioxidants, add complex compounds between fats and aromatic rings of antioxidants (Subandi, 2018). From this reaction, the ovarian granulosa cells can grow and proliferate and there is cell expansion (expansion) even with a low level of confluence.

Based on the calculation of the level of viability Goat ovarian granulosa cells with the provision of kesambi leaf extract (Scheichera oleosa) at different levels of passage (table 2) shows that in passage I the value of the level of viability in treatment $\mathrm{K}$ shows a significant difference with treatment $\mathrm{P}_{1}, \mathrm{P}_{2}, \mathrm{P}_{3}$ and $P 4$. However, there are significant differences in each treatment $\mathrm{P}_{1}, \mathrm{P}_{2}, \mathrm{P}_{3}$ and $\mathrm{P}_{4}(\mathrm{p}<0.05)$. The value of the highest level of viability is in the $\mathrm{P} 4$ treatment.

In the second passage, the values of the viability level of ovarian granulosa cells in $\mathrm{K}, \mathrm{P} 1$ and $\mathrm{P}_{2}$ treatment showed significant differences $(p<0.05)$. However, there are significant differences in the $\mathrm{P}_{3}$ and $\mathrm{P}_{4}$ treatments $(p<0.05)$. The value of the highest level of viability in $\mathrm{P} 2$ treatment.

In the third passage, the viability level of ovarian granulosa cells in $\mathrm{K}$ and $\mathrm{P}_{3}$ treatment did not show a significant difference ( $p<0.05)$. However, there are significant differences in the treatment of $\mathrm{P}_{1}, \mathrm{P}_{2}$ and $\mathrm{P}_{4}(\mathrm{p}<0.05)$. The highest level of confluence in treatment $\mathrm{P} 1$.

Based on these results, giving kesambi leaf extract (Scheichera oleosa) gave a different response to the level of cell viability in each passage. In passage I the highest viability value was found in treatment P4 (22.79) with the highest extract dose (2.5\%). In the second passage, the highest viability value was in $\mathrm{P} 2$ treatment (20.71) by giving the extract dose $1.5 \%$. Whereas in the third passage the highest viability value was in treatment $\mathrm{P} 1$ (19.7) with a dose of $1 \%$. As shown in the chart below. 


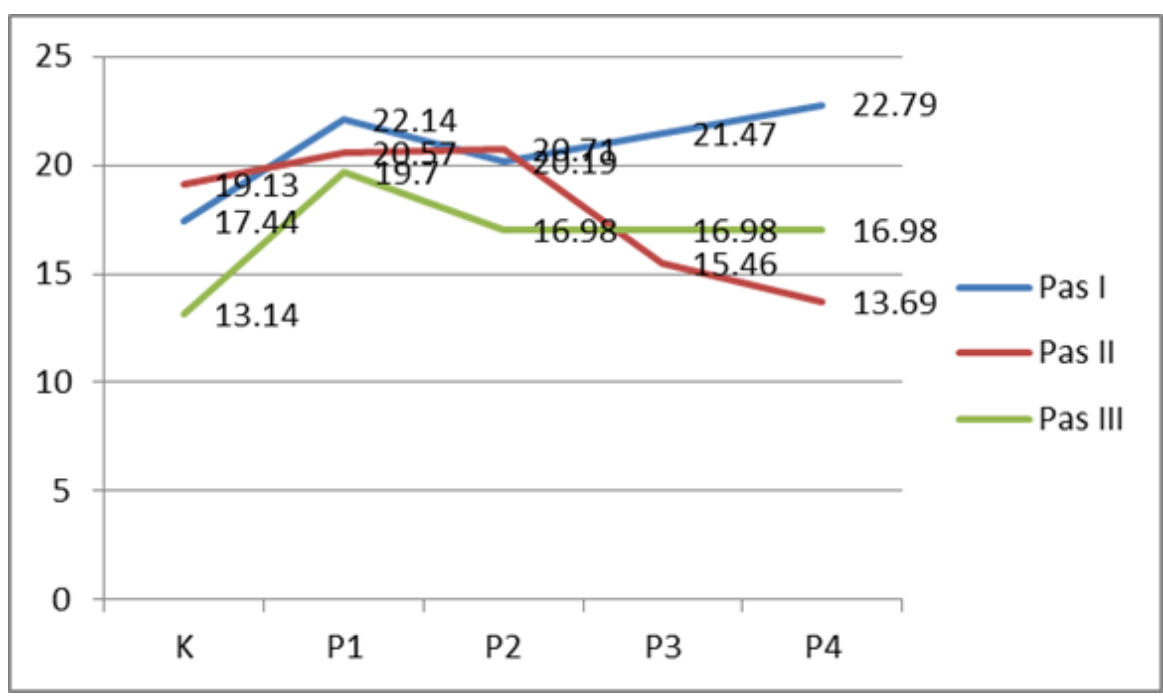

Figure 4.2 Level of viability of granulosa cells goat ovary by giving kesambi leaf extract (Scheichera oleosa) at different levels of passages

According to the graph above, the value of the level of viability of granulosa cells by giving kesambi leaf extract (Scheichera oleosa) shows that the stable environmental conditions of cells in cells greatly affect the viability of these cells. In passage I, cells can maintain viability well with the largest dose of kesambi leaf extract (Scheichera oleosa). However, in the second and third passages the cells experienced a decrease in viability even though the dose of kesambi leaf extract (Scheichera oleosa) was administered at an intermediate level.

This shows that the increase in the viability of granulosa cells is due to the metabolic processes in granulosa cells that occur well at optimal conditions. In this metabolic process, ATP will be produced which will be used by cells to proliferate and differentiate so that the viability of cells that can survive is greater (Kalanjati, 2006).

High cell viability can also be influenced by the membrane in the cell which is able to maintain its permebility. This is because the plasma membrane exchanges material between cells and their environment. $\mathrm{Na}+, \mathrm{K}+$ and $\mathrm{Ca}+$ are actively transported across the cell membrane by means of integral membrane protein channels. Along with active transport, diffusion and osmosis, cell nutrients and other substances needed by cells are also transported (Kalanjati, 2006).

The different levels of viability in each treatment at different passages are also thought to be influenced by the toxicity factors in the extracts given, although toxicity testing has not been carried out in this study. Toxic conditions are probably caused because the extract has a low molecular weight so that it penetrates more quickly into the cell then the cell experiences osmotic shock. so that causes a decrease in the concentration of $\mathrm{Na}+$ and $\mathrm{K}+$ ions. The condition of decreasing $\mathrm{Na}+$ and $\mathrm{K}+$ ions certainly affects the physiological condition of the cell. Some of the effects caused are gene expression, deoxyribonucleicacid (DNA) recombination, and actin depolymerization (Pogorelov \& Katkov, 2007).

\section{CONCLUSION}

Based on the results of the study, it can be concluded that the characteristics of the granulosa cells of goat ovaries by giving kesambi leaf extract (Scheichera oleosa) at different passages are at the level of confluence showing the highest value in passage I, namely treatment P1. Meanwhile, 
the level of viability shows the highest value in passage I, namely treatment $\mathrm{P} 4$.

\section{REFERENCES}

Anuragi, J. L., \& Mishra, R. (2017). Ethnomedicinal study of Schleichera oleosa among the tribals of Satna (M.P.). 3(3), 3 .

Arundina, I., \& Suardita, K. (2014). Efek pegagan (Centella asiatica $\mathrm{L}$ ) terhadap proliferasi mesenchymal stem cell (Effect of pegagan (Centella asiatica L) to mesenchymal stem cell proliferation). Journal of Dentomaxillofacial Science, 13(1), 43. https://doi.org/10.15562/jdmfs.v1311.386

Bhatia, H., Kaur, J., Nandi, S., Gurnani, V., Chowdhury, A., Reddy, P. H., Vashishtha, A., \& Rathi, B. (2013). A review on Schleichera oleosa: Pharmacological and environmental aspects. Journal of Pharmacy Research, 6(1), 224-229. https://doi.org/10.1016/j.jopr.2012.11.003

Budiono, D. (2018). Karakterisasi Rat Embryonic Fibroblast (Ref) PascaKriopreservasi Lambat Pada Tingkat Pasase Yang Berbeda. Institut Pertanian Bogor.

CABI. (2020). Schleichera oleosa (Macassar oil tree). Https://Www.Cabi.Org/ Isc/Datasheet/49004 \#toidentity.

Freshney, ian. (2016). Culture of Animal Cells: A Manual of Basic Technique and Specialized Applications, 7th Edition.

Hati, R. (2016). Pengaruh Ekstrak Ethanol Daun Sisik Naga (Pyrrosia pilosellaides) Terhadap Tingkat Kematangan Folikel Ovarium Kambing (Capra Aegagrus Hircus) Secara In Vitro. uin maulana malik ibrahim malang.

Holil, K., \& Griana, T. P. (2020). Analisis Fitokimia dan Aktivitas Antioksidan Ekstrak Daun Kesambi (Schleichera oleosa) Metode DPPH. 5 .

Kalanjati, woro. (2006). Perbedaan Konfluensitas dan Viabilitas Sel Kultur
Primer Sel Fibroblas Dari Jaringan Daun Telingan Rusa Bawean (Axis kuhlii) Pada Medium TCM 199 dan MEM. Universitas Airlangga.

Kwist, K., Bridges, W. C., \& Burg, K. J. L. (2016). The effect of cell passage number on osteogenic and adipogenic characteristics of D1 cells. Cytotechnology, 68(4), 1661-1667. https://doi.org/10.1007/s10616-0159883-8

Moreau, R. A., Whitaker, B. D., \& Hicks, K. B. (2002). Phytosterols, phytostanols, and their conjugates in foods: Structural diversity, quantitative analysis, and health-promoting uses. Progress in Lipid Research, 41(6), 457-500. https://doi.org/10.1016/S01637827(02)00006-1

Panche, A. N., Diwan, A. D., \& Chandra, S. R. (2016). Flavonoids: An overview. Journal of Nutritional Science, 5, e47. https://doi.org/10.1017/jns.2016.41

Parwata, I. (2016). Antioksidan Bahan Ajar. Pasca Sarjana Universitas Udayana.

Pogorelov, A., \& Katkov, igor. (2007). Influence of Exposure to vitrification solutions on 2-cell mouse embryos: I. Intracellular potassium and sodium content. PubMed, 26(6), 403-408.

Rahmawati, M. (2014). Potensi Ekstrak Daun Widuri (Calotropis gigantea) Sebagai Obat Antikanker Fibrosarkoma. uin maliki press.

Sitorus, M. S. (2013). Imunoekspresi Ki-67 Pada Tumor Payudara Tikus Wistar Yang Diinokulasi Tumor Terinduksi Benzo(A) Pyrene Dan Diberikan Ekstrak Daun Sirsak. Universitas Sumatra Utara.

subandi, imam. (2018). Profil Protein Ovarium Tikus Putih (Rattus norvegicus) Betina Setelah Pemberian Ekstrak Etanol Daun Sisik Naga. uin maulana malik ibrahim malang.

Sumiati, T., Gardenia, L., \& Sunarto, A. (2009). PEMBUATAN KULTUR SEL PRIMER DARI SIRIP EKOR IKAN MAS (Cyprinus carpio). Jurnal Riset Akuakultur, 4(1), 
107.

https://doi.org/10.15578/jra.4.1.2009.107

$-116$

Waseh, laneng. (2016). Pengaruh Lama Paparan Murottal Surat Al-Fatihah Terhadap Proliferasi Sel Granulosa

Kambing (Capra Aegagrus Hircus)

Secara In Vitro. uin maulana malik ibrahim malang. 